\title{
Professional norms and physician behavior: \\ homo oeconomicus or homo hippocraticus?
}

\author{
Iris Kesternich \\ Department of Economics, University of Leuven \\ Heiner Schumacher \\ Department of Economics, University of Leuven \\ Joachim Winter \\ Department of Economics, University of Munich \\ Munich Center for Health Economics (MC-Health) \\ Munich Research Institute for the Economics of Aging (MEA)
}

\begin{abstract}
Physicians' treatment decisions determine the level of health care spending to a large extent. The analysis of physician agency describes how doctors trade off their own and their patients' benefits, with a third party (such as the collective of insured individuals or the taxpayers) bearing the costs. Professional norms are viewed as restraining physicians' self-interest and as introducing altruism towards the patient. We present a controlled experiment that analyzes the impact of professional norms on prospective physicians' trade-offs between their own profits, the patients' benefits, and the payers' expenses for medical care. Our data support the notion that professional norms derived from the Hippocratic tradition shift weight to the patient in physicians' decisions while decreasing their self-interest and efficiency concerns.
\end{abstract}

Keywords: social preferences, allocation of medical resources, professional norms JEL classification: A13, I19, C72, C91

* Corresponding author: Iris Kesternich, e-mail: iris.kesternich@kuleuven.be

Acknowledgements: We would like to thank the editor and the referees; Randall Ellis, Dirk Engelmann, Martin Kocher, Darius Ladkawalla, Albert Ma, and Henry Mak; seminar audiences at Aarhus University, the Harvard Health Care Policy Center, the Kelly School of Business, and the Universities of Copenhagen, Hamburg, Michigan, and Stirling; and participants of the 2014 Workshop on Behavioral and Experimental Health Economics at the University of Oslo and the DGGÖ Conference in Munich for valuable comments and discussions. We would also like to thank Suzan Elshout and the team of CentERdata, Tilburg, for implementing the internet experiment; René Cyranek and the MELESSA team for supporting the fieldwork; and Hendrik Brackmann for excellent research assistance. We are grateful to Martin Fischer and Matthias Holzer for their help in fielding this study with a sample of Munich medical students. The third author thanks the Center for Health and Well-Being at Princeton University for its hospitality. Informed consent for participation in this study was obtained from all subjects. The study has been approved by the ethics committee of the University of Munich's Medical School (project no. 260-12). We acknowledge financial support by the Deutsche Forschungsgemeinschaft through SFB/TR 15. 


\section{Introduction}

"Shopkeepers do not swear oaths about shopkeeping. Neither do investors swear oaths about investment. But in most places in the world, doctors swear oaths about doctoring." (Sulmasy, 1999)

Professional norms such as the Hippocratic Oath have governed physician practice since ancient times. It has been argued that norms, which protect the patient and constrain the physician's self-interest, exist because of the special nature of the commodity health. In his seminal analysis of health-care markets, Arrow observes that the "expected behavior" of a physician is quite different from that of business men in general: "His behavior is supposed to be governed by a concern for the customer's welfare which would not be expected of a salesman" (1963, p. 949) 11 Health economists have thus built models of physician behavior in which patients' health or benefits are included in physicians' utility functions, in addition to their own income or consumption (Arrow, 1963; Fuchs, 1974; McGuire, 2000).

Physician ethics traditionally govern physicians' concerns for patients - but what about the concern for health care cost and thus for society as a whole? Medical technologies vary widely in their cost-benefit ratios. Still, politicians and insurance companies are largely unable to restrict physicians in their medical decisions. This is frequently grounded in legal reasons. In the U.S., for example, state laws oblige insurers to pay for any medically necessary service (Chandra and Skinner, 2012). A professional norm which focuses solely on the patient, however, does not reflect the cost implications of treatment choices. Thus, medical ethics and financial incentives may imply that even procedures that benefit patients only weakly are widely used, resulting in large costs for the health care system (Chandra and Skinner, 2012). The World Medical Association's Medical Ethics Manual (WMA, 2009) devotes one of six chapters to the relationship between the physician and society, thus acknowledging its importance for physician ethics today. At

${ }^{1}$ Arrow (1963) discusses several aspects of the special nature of health: Illness and death decrease not only individuals' income-earning possibilities, but also the possibilities to enjoy any other commodity. Yet, unlike any other basic commodities such as food, health losses cannot be avoided through a sufficient level of income. In addition, physicians are experts, because medical knowledge is largely concentrated among them. Arrow also points out that the production of health services and the final product cannot be separated, which means that patients cannot test the service provided in advance. 
the same time, the manual states that "the Hippocratic tradition of medical ethics has little guidance to offer with regard to relationships with society" (p. 65).

In this paper, we address the question of how professional norms change physicians' behavior when they trade off their own profit, and the patient's benefit, and the cost of medical care to those who pay for it. No reliable empirical evidence exists on this question, and it is unlikely that observational studies will be able to uncover causal relationships, as it is hard to imagine how professional norms could be manipulated in real-world settings. Thus, the effects of such norms are confounded with other factors such as financial incentives, peer pressure, uncertainty about costs and benefits, and fear of being sued for malpractice. We therefore employ a controlled experiment to study the behavior of individuals in a situation in which decisions and incentives resemble those of physicians. Our subjects are 266 medical students from two large German universities.

Specifically, the novel experimental task allows us to observe how subjects (whom we call deciders in the following) trade off between three quantities: their own profit, the payoff of a receiver (the patient), and the contributions of a group of payers (the taxpayers or the collective of insured individuals). The task is a simple distribution game where the decider chooses the provision of a good which benefits the receiver but is paid for by several payers. The efficiency of providing the good, i. e., the mapping of its cost into the receiver's payoff, can be manipulated experimentally:2

In order to test whether there is any effect of professional norms over and above the type of social preferences usually reported in distribution games, we vary the choice tasks along three dimensions. First, we manipulate the salience of professional norms. Before seeing the choice task, all subjects answer a questionnaire on their socio-economic background. At the end of this survey, one half of our subjects is shown a modern version of the Hippocratic Oath embedded in a survey question. In the control group, this particular question is not asked (while the overall length of the survey is roughly the same). Second, we manipulate the framing of the experimental task. One half of our subjects see the choice task in a neutral framing (i. e., we call the player roles "decider", "receiver", and "payers"), the other half sees it in a medical decision framing (where the player roles are "physician", "patient", and the good is a "medical treatment"). Third, we manipulate

\footnotetext{
${ }^{2}$ The experimental task was developed in a related study (Schumacher et al., 2014) which, however, focuses on the effect of the size of the groups of payers and does not contain any framing manipulations with respect to professional norms.
} 
the identity of the receiver. For one half of our subjects, the receiver is another student subject, for the other half it is a real-world charity that is concerned with actual patients (the Munich children's hospice). We are primarily interested in the combination of the "medical framing" and the "hospice receiver", which resembles the real-world situation faced by a physician ${ }^{3}$

Each subject plays twelve distribution games. The first four games are standard dictator games. In the remaining eight games, which we call cost dispersion games, the payers are added as a third party. In these games, providing more of the good increases the receiver's payoff at the cost of the payers. The decider may or may not benefit from the provision of the good.

Our main findings are as follows. First, in the dictator games the decisions of medical students are similar to those of other types of subjects (Camerer, 2003 or Engel, 2011). Provision of the good is not, on average, higher in a medical framing, but it is significantly increased when the receiver is a charity that cares for real patients rather than a student receiver.

Second, our most important finding is that there is a strong and positive effect of the Hippocratic Oath on the average amount of the good provided. This effect is only present in the medical, but not in the neutral framing. In a medical setting, the salience of the Hippocratic Oath increases the decider's altruism towards the receiver and thus helps mitigate the agency problem between physician and patient.

Third, the efficiency of providing the good plays an important role in subjects' decisions; this is even the case in the medical framing and with a hospice receiver. Efficiency concerns are somewhat weaker in the medical framing than in the neutral framing. Salience of the Hippocratic Oath weakens efficiency concerns in the medical framing when the receiver is a patient charity - the situation that resembles medical decision making the most. These results suggest that the fact that Hippocratic Oath does not mention the cost or efficiency of the provision of medical care reduce efficiency concerns that are present otherwise.

\footnotetext{
${ }^{3}$ In an earlier version of this paper, we reported data from a similar experiment conducted in 2012. That experiment used only a neutral framing which, however, followed after a long survey on medical students' job experiences and a hypothetical choice experiment on their job preferences. The results we obtained in that earlier study are similar to the ones for the medical framing treatment we report here. We thank a referee for encouraging us to consider an explicit medical framing.
} 
Forth, in those games that involve payers as a third party, we find that average provision is the larger the more the deciders themselves benefit from providing the good. Efficiency concerns are still present in these types of games. Even when other subjects have to bear the costs, more of the good is provided when the receiver is a medical charity. In the cost dispersion games, the salience of the Hippocratic Oath generally does not increase the provision of the good. Only in the medical treatment and if the receiver is the hospice, the effect of the Hippocratic Oath is positive but it is not statistically significant. When the receiver is another student, the Hippocratic Oath even tends to reduce the provision of the good.

These are striking results. They highlight that prospective physicians, just like individuals in many experimental studies before, exhibit a combination of selfish and other-regarding preferences, and that they take the welfare of all parties into account. Most importantly, altruism is increased by a professional norm that shifts all the weight towards the receiver. In the interaction between physicians and their patients, the professional norm reflected in the Hippocratic Oath mitigates a fundamental agency conflict. Thus, our findings support the notion that professional norms are "society's way of coping with market failure" (Arrow, 1971). Even though it mostly excludes a relevant group of stakeholders (the payers of medical services), we find only weak evidence that the physicians' professional norm decreases concerns for the payers. In the situation that resembles real-world medical decisions the most, efficiency concerns are weakened when the Hippocratic Oath is present. The remainder of this paper is structured as follows. We review the role of the Hippocratic Oath in medical practice and related literature in Section 2. Section 3 describes the methods we use; it contains descriptions of the experimental design, lists the conjectures we make, and describes the field procedures and the sample. We present the results in Section 4, and provide a discussion and draw some conclusions in Section 5.

\section{Background and literature review}

In this section, we first review the history and current role of the Hippocratic Oath (Subsection 2.1). We then provide a brief review of the literature on physician behavior (Subsection 2.2) and on preferences in simple distribution games (Subsection 2.3). 


\title{
2.1 The Hippocratic Oath
}

For centuries, the Hippocratic Oath has been the key manifestation of the ethics that governs the relationship between physicians and their patients (and their teachers, in the original version of the oath). The Hippocratic Oath goes back to the fourth century B.C.E. to either Hippocrates himself or one of his scholars (Hulkower, 2010 and Miles, 2005). Outside of Greece, it is first recorded to have been sworn in France in the ninth century, in Sweden in the tenth and eleventh century (Macer, 1990), and in Germany in the early 16th century (Smith, 2008). It became part of the curricula of medical schools already during the Middle Ages (Crawshaw, 1970). The share of medical schools in the U.S. where some variation of the Hippocratic Oath is sworn has been constantly increasing since the beginning of the 20th century, reaching almost 100 percent in 1992 (Orr et al., 1997).

As a response to the medical crimes that had taken place in Nazi Germany, a modern version of the Hippocratic Oath was composed in 1948 (Sohl and Bassford, 1986). This version is referred to as the Declaration of Geneva. It reads:

\begin{abstract}
At the time of being admitted as a member of the medical profession: I solemnly pledge to consecrate my life to the service of humanity; I will give to my teachers the respect and gratitude which is their due; I will practice my profession with conscience and dignity; The health and life of my patient will be my first consideration; I will respect the secrets which are confided in me; I will maintain by all means in my power, the honor and the noble traditions of the medical profession; My colleagues will be my brothers; I will not permit considerations of religion, nationality, race, party politics or social standing to intervene between my duty and my patient; I will maintain the utmost respect for human life, from the time of its conception, even under threat, I will not use my medical knowledge contrary to the laws of humanity; I make these promises solemnly, freely, and upon my honor.
\end{abstract}

Some form of this oath, in most cases the Declaration of Geneva, is still sworn by the large majority of graduates from medical schools today (Orr et al., 1997). Oaths are usually sworn in a public context; they carry a moral weight; their commitment is general both in context and over time; and oaths place the honor of the swearer at risk in the case that 
they are broken (Sulmasy, 1999). The Hippocratic Oath is central to modern Western ethics. For decades, both the American Medical Association and the British Medical Association began their Code of Medical Ethics with references to the Hippocratic Oath: "The Oath of Hippocrates has remained in Western civilization as an expression of ideal conduct for the physician" (American Medical Association, 1996).

The Hippocratic Oath commits the physician to work towards the good of the patient. While the oath does not mention the physician's own benefit, it certainly suggests that it should only be secondary to that of the patient. Importantly, the Geneva version of the oath does not mention the cost of treatment or the fact that resources for treatment are limited. However, there is a version of the oath that does refer to societal welfare. Louis Lasagna, academic dean of the School of Medicine at Tufts University, developed a modern version of the Hippocratic Oath, containing the following lines: "I will apply, for the benefit of the sick, all measures [that] are required, avoiding those twin traps of

overtreatment and therapeutic nihilism. [...] I will remember that I remain a member of society, with special obligations to all my fellow human beings, those sound of mind and body as well as the infirm."

\subsection{Physician behavior in health economics}

In this selective discussion of the literature on physician behavior, reviewed in much more detail by McGuire (2000), we want to stress two points. First, models of physician behavior in health economics have largely abstracted from the presence of a third party (the payers). Second, the fact that physicians ignore payers when making treatment choices has been identified as one of the main reasons why health-care costs are so high. Following the Hippocratic tradition, physician ethics are defined to encompass only the concern for the patient. Traditionally, physician behavior has been analyzed under the assumption of pure income-maximization. When the physician has better information than the patient, she may recommend a greater quantity of care than what the patient actually needs ("physician induced demand"). However, it is now accepted that physician ethics encompass some concern for the patient. In more recent models, the patient's health or benefit (Allard et al., 2011; Chandra and Skinner, 2012; Choné and Ma, 2011; Ellis and McGuire, 1986; Liu and Ma, 2013) or the quality of treatment (Chalkley and Malcomson, 1998) are also included in the physician's utility function. Here, the benchmark for choos- 
ing quantity and quality of care is the patient's well-being. Physicians are assumed to be altruistic towards their patients, even when facing a trade-off between their own and their patients' benefits. By putting a break on the physicians' income maximization motive, physicians' professional norms at least potentially increase total welfare as they ensure higher physician effort or a more patient-oriented choice between treatment options.

However, physicians' treatment decisions do not only affect patient welfare. They also have cost implications for the payers of health care. Thus, a broader definition of medical ethics might also encompass the physician's relationship with society. This idea is not new by any means. As pointed out by Baker and McCullough (2009), the term "physician ethics" was coined in 1803 by the British physician Thomas Percival. He summarizes it as "the professional duties of physicians and surgeons to their patients, their fellow practitioners, to the public, and in law courts" (p. 3). Today, the World Medical Association's Medical Ethics Manual devotes one chapter (of six) to the relationship between the physician and society: "Medicine [...] takes place in a context of government, and corporate organization and funding" (WMA, 2009, p. 65). This is, however, not the view taken in the theoretical literature on physician agency. Concerns for total, and not only the patients', welfare are rarely modeled as constraints.4

Only few studies attempt to quantify empirically the impact of professional norms on physician behavior, as it is almost impossible to vary the degree of professional norms in real-world settings. Thus, their effects are confounded with other factors such as financial incentives, peer pressure, uncertainty about costs and benefits, and fear of being sued for malpractice. Currie and MacLeod's (2008) findings on the effect of tort reform on birth outcomes provide some evidence against the notion that physicians follow a principle of "First do no harm." After a tort reform, physicians were found to avoid unnecessary and harmful procedures, because malpractice risk was aligned more closely with the physicians' own actions. In turn, this suggests that they were performing these types of procedures before the reform. However, even though birth complications declined after the reform, indicators of infant health did not change a lot, indicating that in severe cases, physicians did not change their behavior significantly. There is, however, also evidence that physicians do intrinsically care about the quality of the services they

${ }^{4}$ One rare exception is Chandra and Skinner (2012) who assume an "ethical norm against spending too much of the nation's resources" (p.656). 
provide. Kolstad (2013) analyses the effects of performance assessments on physician behavior and finds that physicians are willing to forgo profits to provide better quality. The small but growing experimental literature on physician choices (or those of subjects in situations resembling those faced by physicians) has mostly focused on their reactions to the incentives they face with respect to their own income. For instance, Brosig-Koch et al. (2013, 2015a, 2015b) and Hennig-Schmidt et al. (2011) study the effects of different payment systems. Hennig-Schmidt and Wiesen (2014) compare medical and non-medical students with regard their willingness to sacrifice own profit for their patients' benefit. They find that medical students are more willing to do so than non-medical students. Godager and Wiesen (2013) design a laboratory experiment in which a patient benefits from the physician's choices which allows them to quantify the utility weights of physicians' own payoffs and their patients' health. They find that physicians apply a positive weight to patients' health benefit, but that they vary substantially in their degree of altruism. In their experiment, professional norms are not varied; all choices are made under one of the professional norm treatments we study in the present paper, namely that the receiver of the payoff generated by prospective physicians' choices is a charity that cares for real patients. The choice situation we study includes a third party - the payers -, and it allows us to study the effect of a professional norm on the choices of prospective physicians.

\subsection{Heterogeneity and context dependence of social preferences}

The role of altruism in physicians' choices has been stressed in the health economics literature, as reviewed above. For the most part independently, a large literature in the field of behavioral economics documents that many individuals can be described by other-regarding preferences (not just those working in specific professions such as health care) $5^{5}$ A number of studies from the lab and the field show that a significant share of individuals exhibit efficiency concerns in simple distribution games (Andreoni and Miller, 2002; Charness and Rabin, 2002; Engelmann and Strobel, 2004, 2007; Fisman et al., 2007, 2014). Men care more about efficiency than women (Andreoni and Vesterlund, 2001; Schildberg-Hoerisch, 2010). Messner et al. (2010) demonstrate that behavior in an experiment where subjects choose the distribution of payoffs through elections can best

\footnotetext{
${ }^{5}$ See Kerschbamer (2015) for a recent overview over different distributional preference types.
} 
be explained through concerns for efficiency. We therefore conjecture that physicians not only take into account the patient's welfare, but also the welfare of those who pay for the services provided (insurance holders or the general public).

Our paper is also related to an emerging literature on the context-dependence of preferences. Benjamin et al. (2010) use a background questionnaire to prime social identity (Asian-American versus white American). They find that making social identity salient to Asian-American subjects makes them more patient in a choice task, while there is no such effect for white American subjects. Cohn et al. (2014) use survey questions to prime professional identity. In their experiment, individuals working in a large, international bank do not act more dishonestly than employees in other industries. However, when their professional identity as bankers is made salient to them, they become on average more dishonest.

\section{Methods}

The aim of our experiment is to study how professional norms change distributional preferences. More specifically, we test whether the salience of the Hippocratic Oath affects how decision makers (whose situation is similar to that faced by physicians) trade off their own payoff, the payoff of a passive receiver (a patient), and the payoff of a passive third party (a group of insurance or tax payers). Our sample consists of medical students. For these subjects both distributional decisions such as those we study and professional norms like the Hippocratic Oath will be relevant in their professional lives - i.e., when they make decisions about medical care provision. In order to facilitate access to this population, the experiment was conducted over the internet. We first describe the design

of the experiment (Subsection 3.1) and state the conjectures that we will test (Subsection 3.2). We then describe the sample and the implementation (Subsection 3.3).

\subsection{Design of the experiment}

We adopt a novel experimental design, developed in related work (Schumacher et al., 2014) that analyzes preferences in games with concentrated benefits and dispersed costs. Each subject is randomly paired up with a group of other subjects. Each group consists of one decider, one receiver, and three payers. In each game, the decider chooses the provision 
$x \in\{0,1, \ldots, 10\}$ of a good which affects her own payoff, $\pi_{D}=15+a x$, the payoff of a single receiver, $\pi_{R}=5+b x$, and the payoff of three payers, with $\pi_{P}=15-c x$ for each of them. The receiver has an endowment of 5 tokens which is lower than that of the other parties (whose endowment is 15 tokens). Thus, a motive exists to redistribute payoffs. The parameters $a, b$, and $c$ represent the number of tokens that each party receives or pays per unit of the good provided. The values of these parameters are summarized in Table 1. In total, there are twelve different distribution games. Each subject plays all twelve games.

- Insert Table 1 about here. -

The first four games are standard dictator games in which the decider shares her initial endowment with the receiver (i. e., we have $c=0$ so that the payers are passive bystanders whose payoff is not affected). Thus, the provision of the good is costly for the decider and benefits the receiver. We vary $b$, the receiver's marginal payoff, between the dictator games to change the efficiency of providing the good.

In the remaining eight games, the cost dispersion games, we analyze distributional preferences in settings in which it is not the decider herself but the payers who bear the costs of provision. In the interested cost dispersion games (Games 5-8), both the decider and the receiver benefit from the provision of the good. In the disinterested cost dispersion games (Games 9-12), only the receiver benefits from the provision of the good. In both types of games, we again vary the receiver's marginal payoff $b$.

In order to study the effect of professional norms, we implemented three treatment manipulations. The first treatment is the professional norm manipulation which uses a conceptual priming approach to vary the salience of the Hippocratic Oath. Priming refers to the temporary activation of an individual's mental representations and the effect of this activation on behavior in an unrelated subsequent task. As priming instruments, researchers have used the writing of essays, responding to questionnaires, the "Scrambled Sentence Test", or subliminal presentations of priming words (see Bargh and Chartrand, 2000 for an overview). Before playing the twelve distribution games, subjects answer a questionnaire consisting of 21 questions which cover socio-demographic variables and address the subjects' occupational choices. With probability $1 / 2$, a subject sees an additional survey question that contains a modern version of the Hippocratic Oath after the survey and before reading the instructions of the experiment. With reverse probability, 
the question containing the Hippocratic Oath is not presented. The exact wording of the survey question is

In Germany, physicians do not need to swear the 'Hippocratic Oath' anymore before receiving their license to practice. The current version of the Geneva Declaration of the World Medical Association reads: [...] In your opinion, how important should the Hippocratic Oath be for practicing physicians today?

The second treatment is the framing manipulation. With probability $1 / 2$ a subject receives the instructions in a neutral framing without any reference to medical decision making. With reverse probability, the instructions are presented in the context of medical decision making (similar to Hennig-Schmidt et al. 2011), i. e., the decider is called "physician", the receiver is called "patient", and the good is a "medical treatment". The structure of the instructions is the same in both framings except that in the medical framing we add the following information (in German): "We know that in reality a physician's decision is more complex. However, we can only capture an abstract decision situation in this experiment. Please assume therefore that costs and benefits of all parties can be expressed in monetary units."

The third treatment is the receiver type manipulation. With probability $1 / 2$ the receiver is another student subject, and with reverse probability the receiver is a local charity organization that cares for real patients (the Munich Children's Hospice). If the receiver is the hospice, real patients outside of the lab benefit from provision choices made in the experiment.

\subsection{Conjectures}

The Hippocratic Oath stresses patient welfare, but does not comprise a concern for societal welfare or the payers of medical care. We therefore conjecture that its salience increases concerns for the receiver in all distribution games, in particular, if the decision is taking place in a medical decision making context. The provision of the good should then increase in both the dictator and cost dispersion games when we expose subjects to the professional norm. We test Conjectures 1 and 2 with the data from the dictator Games 1-4:

Conjecture 1: If the Hippocratic Oath is salient, the decider provides more of the good, increasing the receiver's payoff and decreasing her own. 
Conjecture 2: The increase in the provision of the good associated with making the Hippocratic Oath salient varies with the efficiency of providing the good.

Specifically, we expect that relative increase to be larger when it is less efficient to provide the good.

A third conjecture concerning the effect of the identity of the receiver is tested with the data from all games:

Conjecture 3: Compared with a situation in which the receiver is another student, the decider provides more of the good if the receiver is a real-world charity that cares for actual patients.

In order to analyze decisions when there is a separate group of payers, we also use the data from the interested and disinterested cost dispersion Games 5-12:

Conjecture 4: If the Hippocratic Oath is salient, the decider provides more of the good, increasing the receiver's payoff and decreasing the payers' payoffs.

Conjecture 5: We expect the effects described in Conjectures 1 through 4 to be stronger under the medical framing than under the neutral framing.

\subsection{Implementation and sample}

The experiment was conducted over the internet and administered by CentERdata, Tilburg University $]^{6}$ The Online Appendix contains translations of the survey instrument and of the instructions for the experiment. Moreover, we present all screens shown to the subjects in the Online Appendix.

The experimental design comprises three manipulations which are randomized independently, resulting in $2 \times 2 \times 2$ framings. Subjects are randomly assigned to one of these eight cells. Each subject makes the same twelve decisions (one in each of the twelve games defined above) with the framing being kept fixed. To control for order effects, we randomize the sequence of games. To simplify decision making for our subjects, the randomization keeps blocks of similar games together. The first four games are always the dictator games, either in descending or ascending order. The next games are the

${ }^{6}$ CentERdata has more than a decade of experience running internet surveys and experiments. Among other studies, CentERdata maintains the Dutch Household Survey (DHS) and the LISS Internet Panel. For more information, see http://centerdata.nl/en. 
four interested or the four disinterested cost dispersion games (in descending or ascending order). Then the remaining games are played (in descending or ascending order) $]^{7}$ We include order dummies in our regression analysis and find no evidence of order effects. We only conduct between-subject comparisons.

To conduct the experiment in an economical manner, we follow the strategy method 8 Subjects are informed that they will be assigned randomly to groups of five (when the receiver is another student) or four (when the receiver is the hospice). After the experiment, we randomly pick one game for each group that will be implemented. We also randomly select one subject from each group who takes on the role of the decider and (when the receiver is a student) one subject who takes on the role of the receiver. The other three subjects of the group take on the role of payers. The decider's action in the chosen game then determines the payoffs of all parties. Hence, a subject's decision can only affect her own payoff if she is chosen to be the decider, but not if she is in the role of the receiver or payer. This is explicitly communicated to participants in the instructions.

Subjects do not receive feedback about the actions of others except through their payment after the experiment. When making their decisions, subjects receive detailed information about the (potential) consequences of their actions on the decision screen: their own payoff, the receiver's payoff, the payoff of each payer, and the group payoff (see the Online Appendix for the screenshot of a typical decision screen).

We recruited 266 medical students from the University of Munich and the Technical University of Munich. These students were in the second, "clinical" half of their studies, comparable to incoming medical school students in the U.S. system. Most of them were between 20 and 24 years of age (with a mean age of 22.1 years); 60.2 percent were female. Students were invited to participate by e-mail in December 2014; data collection ended in January 2015. After answering the questionnaire, they started the experiment. The instructions carefully explained the design using several numerical examples. Subjects could participate in the experiment only if they answered two control questions correctly.

\footnotetext{
7 Thus, subjects were assigned to one of four sequences of games, namely Sequence 1, 1-2-3-4-5-6-7-8-910-11-12; Sequence 2, 4-3-2-1-8-7-6-5-12-11-10-9; Sequence 3, 1-2-3-4-9-10-11-12-5-6-7-8; Sequence 4, 4-3-2-1-12-11-10-9-8-7-6-5.

${ }^{8}$ Avoiding the strategy method would have required us to pay at least four additional (passive) subjects for each decision taken in the experiment. Brandts and Charness (2011) survey the experimental literature that studies whether the strategy method and the direct-response method lead to different results. They find no study in which the treatment effects that are observed with the strategy method are not observed with the direct-response method.
} 
Payments were made one week after the experiment. A participant's payoff of $\pi$ tokens was converted into 0.8 $\pi$ EUR. Average earnings were 10.1 EUR. The median completion time for the questionnaire and the experiment was about 27 minutes 99 The distribution of subjects across the treatments is reported in Table 2.

CentERdata delivered the data from the experimental games in anonymous form (without names and e-mail addresses). The survey software produced and delivered to us a separate dataset containing the information required to make the payments, comprising only the names and the final payoff amounts. In the invitation e-mails and on the first screen of the experiment, we explicitly stated that the survey, experimental data, and personal identifiers would never be combined, other than for the purpose of making the payments.

\section{Results}

In Subsection 4.1, we present our findings regarding the effect of the Hippocratic Oath on behavior in the dictator games and test Conjectures 1 and 2. In Subsection 4.3, we analyze the cost dispersion games and test Conjecture 3. In Subsection 4.2, we study whether the receiver's identity affects distributional preferences and test Conjecture 4. These tests are based on the mean number of units provided in the 12 games, stratified by the eight treatments; these numbers are reported in Tables 3 and $4{ }^{10}$ Throughout, we are mainly interested in the effect of the Hippocratic Oath in medical framing \& hospice receiver treatment, but we discuss the other three cases as well. In Subsection 4.4, we use regression analysis to study interactions between the professional norm and the receiver type manipulations as well as the efficiency of providing the good.

\subsection{Dictator games}

In each dictator game, the decider shares her initial endowment with the receiver while the payers are not affected by the provision of the good. We keep incentives for the decider constant across the dictator games (she loses one token per unit of the good provided).

\footnotetext{
${ }^{9}$ Of the 266 subjects, 4 did not complete all 12 games (the numbers of completed games for these four subjects were $1,3,4$, and 10 , respectively). We leave these subjects in our analysis, but results are quantitatively the same if we do not.

${ }^{10}$ In what follows, all $p$-values we report refer to one-sided $t$-tests. We have also conducted MannWhitney U-tests and Fisher-Pitman permutation tests as a robustness check and found the substantive conclusions of the paper unchanged.
} 
The receiver's marginal benefit decreases as subjects proceed from Game 1 to Game 4, and so does the efficiency of providing the good.

- Insert Table 3 about here. -

When the receiver is another student subject, the framing is neutral, and the Hippocratic Oath is not salient, across the dictator games (Games 1-4) the average provision of the good is 31.5 percent of the maximal possible amount, 23.5 percent of subjects give nothing, and those who do give 52.6 percent of the maximum. The regression results reported below show that male subjects react more strongly to the receiver's marginal payoff than female subjects. These results are in line with the large body of evidence on behavior in the dictator game, as summarized by Camerer (2003) or Engel (2011). Importantly, these data confirm that distributional preferences in our sample of medical students are not special 11

- Insert Figure 1 about here. -

We first consider the difference in the mean number of units provided between the treatments with and without the Hippocratic Oath when the other two treatment dimensions are medical framing and hospice receiver (left half of the Table 3 , Part A). The corresponding final payoffs for the decider and the receiver are shown in Figure 1, again separated by the Hippocratic Oath manipulation 12 Across the four dictator games (Games 1-4), subjects provide on average 41.1 percent of the maximal possible amount when the Hippocratic Oath is not shown, while they provide 51.8 percent when it is salient. In three of the four dictator games, the salience of the Hippocratic Oath significantly increases the provision of the good ( $p>0.1$ for Game 1, $p=0.085$ for Game 2, $p=0.021$ for Game 3 , and $p=0.046$ for Game 4). Thus, the weight of the receiver in the decider's utility function increases. In other words, selfish motives get weaker, and altruism toward the receiver gets stronger. This confirms Conjecture 1 for the combination of the medical framing and hospice receiver treatments.

In the medical framing, the effects of the Hippocratic Oath are weaker when the receiver is another student. The differences in the mean number of units provided between the

${ }^{11}$ Since behavior in our dictator games (in which there is a high chance of being in the role of a payer) is comparable to that of other studies, we also conjecture that the role uncertainty in our experiment has no important effect on subjects' behavior.

${ }^{12}$ Significance levels for the differences between the bars in Figure 1 are the same as those for the corresponding tests shown in the top panel of Table 3 
treatments with and without the Hippocratic Oath are statistically significant for Game $1(p=0.020)$ and Game $2(p=0.068)$ but not significant $(p>0.1)$ for Games 3 and 4 . In the neutral framing (Table 3, Part B) we find hardly any significant differences.

We now turn to Conjecture 2 which states that the increase in the provision of the good associated with making the Hippocratic Oath salient is larger if it is more inefficient to provide the good. We again focus on the medical framing \& hospice receiver treatment (left half of 3, Part A). We observe that the relative increase in the provision of the good when the Hippocratic Oath is salient, compared to the treatment when it is not shown, gets larger as subjects proceed from the first to the last of the dictator games. The effect of the Hippocratic Oath on the provision of the good is 10 percent in Game 1, 20 percent in Game 2, 42 percent in Game 3, and 48 percent in Game 4. Thus, the salience of the Hippocratic Oath induces subjects to provide relatively more of the good when it is more inefficient to do so. In other words, efficiency concerns are weakened under the presence of the Hippocratic Oath. This pattern is also visually apparent in Figure 1. However, in all other treatments, we find exactly the opposite pattern - the relative change in the mean number of units provided induced by the salience of the Hippocratic Oath tends to decrease as we move from Game 1 to Game 4. Thus, whether Conjecture 2 holds depends on the framing of the dictator game: The salience of the Hippocratic Oath weakens efficiency concerns only in the medical framing when the receiver is a patient charity. The findings reported in the two previous paragraphs also confirm Conjecture 5. The effects described in both Conjectures 1 and 2 are stronger under the medical than under the neutral framing.

\subsection{Identity of the receiver}

Subjects' distributional preferences may depend on the receiver type. Using the data from our receiver type manipulation, we can check to what extent the provision of the good changes when the receiver is a charity that cares for real patients instead of another student subject. These contrasts are shown in Table 4 (which is a re-ordering of the means reported in Table 3).

\section{- Insert Table 4 about here. -}

In the medical framing treatment with salience of the Hippocratic Oath (right half of Table 4. Part A), the mean number of units provided is larger in all 12 games if the 
receiver is the hospice. The differences are always significantly different from zero in the dictator game and disinterested cost dispersion games but only significant for the first interested cost dispersion game. In the dictator games, the provision of the good increases by about 42.3 percent; in the interested cost dispersion games, the provision of the good increases by 14.8 percent; and in the disinterested cost dispersion games, the provision of the good increases by 37.5 percent. Hence, on average subjects care more about the hospice receiver. In the dictator games, this leads to more altruistic behavior, and in the cost dispersion games to more redistribution from the payers to the receiver. These patterns also arise in the treatments with the neutral framing (Table 4, Part B). These results confirm Conjecture 3 .

A more differentiated picture arises when the Hippocratic Oath is not salient in the medical framing treatment (left half of Table 4. Part A): In each class of game (dictator games, Games 1-4; interested cost dispersion games, Games 5-8; disinterested cost dispersion games, Games 9-12), whether more of the good is provided if the receiver is the hospice compared to another student depends on the efficiency of the game. The effect we observed in all other treatments arises only in the relatively more efficient Games 1, 2, 3, 5, 6, 9, and 10 but not in the relatively less efficient Games 4, 7, 8, 11, and 12 . Thus, again, we can confirm Conjecture 5: The effects of the receiver type manipulation is stronger in the medical than the neutral framing.

\subsection{Cost dispersion games}

We now investigate what happens if there is another party in the game that pays for the good's provision. In the interested cost dispersion games (Games 5-8), both the decider and the receiver benefit from the good's provision, while the payers pay for it. In the disinterested dispersion games (Games 9-12), the decider has no monetary incentives to provide the good. Provision of the good decreases the total group payoff in each of these games.

Conjecture 4, which predicts that salience of the Hippocratic Oath increases the payoff of the receiver even when payers are present, is not supported by the data. In the main treatment of interest (medical framing \& hospice receiver), the salience of Hippocratic Oath is associated with higher mean contributions, but these effects are small and not statistically significant (Table 3). In all other treatments, the effects of the Hippocratic 
Oath are either insignificant, or if they are significant, they show the opposite sign of what we conjectured - i. e., the salience of the Hippocratic Oath decreases provision of the good and thus increases the payoff of those who have to pay for it. Our interpretation of these results is as follows. The Hippocratic Oath governs the relationships between physician and patient, but it has no influence on the relationship between patient and the third party of the payers.

\subsection{Regression analysis}

We now analyze interaction effects among the three orthogonal treatment manipulations as well as changes in efficiency. The results of the regressions that use the dictator game data can be found in Table 5, those based on the cost dispersion games in Table 6. We report linear regressions in which the number of units of the good provided is the dependent variable ${ }^{13}$ Along with the OLS coefficient estimates, we report standard errors clustered at the subject level to account for the fact that we observe multiple decisions for each subject (four for each game type). All regressions contain controls for the sequence of the games; none of them is statistically significant ( $F$-test values are reported in the regression tables). We also report specifications that allow testing for gender effects.

- Insert Table 5 about here. -

The regression shown in Table 5, Column (1) contains only the efficiency level $(a+b)$ and the main effects of the three treatments as independent variables. The constant has the following interpretation: At an efficiency of zero (a situation in which the receiver's benefit varies one-to-one with the amount the decider has to give up), in the neutral framing, with a student receiver, and without the salience of the Hippocratic Oath, deciders in a dictator game situation provide, on average, about 3.39 units of the good. The coefficient estimate of the efficiency variable shows that subjects take the costs and benefits of giving into account: An increase in efficiency by one unit induces an increase of 1.64 units of the good provided $(p<0.01)$. The main effect of the medical framing is not statistically significant. When the receiver is the hospice, subjects provide an additional 1.72 units of

13 The results of corresponding Tobit regressions, which address the fact that provision is restricted to be non-negative and below 10 units, are reported in Tables A.1 and A.2 respectively, in the Appendix. They are not qualitatively different from the OLS results. 
the good, roughly a 60 percent increase $(p<0.01)$. The main effect of the Hippocratic Oath is not significantly different from zero.

The effect of the professional norm becomes evident once we include interaction effects between the treatments in Column (2): The Hippocratic Oath has a positive, statistically significant effect in the medical framing where it increases provision by 1.39 units ( $p=$ 0.030). This confirms the results in Table 3 discussed above. The other interaction effects are not significant.

In Column (3), we investigate whether the effects of the treatments interact with the level of efficiency. We find that in the neutral framing, the Hippocratic Oath even increases efficiency concerns $(p=0.025)$ while in the medical framing, efficiency concerns are weakened as this interaction term is negative $(p=0.044)$, and the coefficient is larger (in absolute terms) than that for the neutral framing. Column (4) includes interactions of a dummy variable for male subjects with the treatment variables and the level of efficiency. Confirming the findings of the literature on dictator games (e.g. Andreoni and Vesterlund, 2001, and Croson and Gneezy, 2009), male subjects give 1.08 units less of the good at an efficiency level of zero $(p=0.103)$ but care more about efficiency - this gender effect amounts to about 0.97 additional units provided per efficiency unit $(p=0.010)$.

Taken together, the regression results reported in Table 5 support Conjecture 1, but only in the medical framing. Regarding Conjecture 2, the results in Column (3) show that while the salience of the Hippocratic Oath increases concerns for efficiency in the neutral framing, in the medical framing the interaction term of efficiency and the Hippocratic Oath is significantly negative and offsets the Oath's main effect. The main effect of the hospice receiver treatment is significant and positive in all regressions reported in Table 3, which provides strong support for Conjecture 3. Finally, we also find support for Conjecture 5: Both the effects of the Hippocratic Oath and also negative efficiency effects of the Hippocratic Oath's salience are stronger under the medical than under the neutral framing.

- Insert Table 6 about here. -

Table 6 reports regressions for the cost dispersion games; the specifications are the same as those reported in Columns (1) through (3) of Table 5. The regressions using the data from the interested cost dispersion games, reported in Columns (1) through (3), confirm that the efficiency of providing the good has a positive and significant effect on the amount 
provided. Also, deciders provide more of the good when the receiver is the hospice. None of the other treatment and interaction dummies are significant in the regressions for the interested cost dispersion games, which might be due to small cell sizes.

Columns (4) through (6) contain the results for the disinterested cost dispersion games. Deciders trade off the receiver's benefit and the costs borne by a group of payers without contributing themselves. Comparing the estimated value of the constant between the regressions shown in Table 6 Column (4) and Table 5 Column (1), we find that average provision almost doubles. This might be explained by the fact that deciders do not have to bear part of the cost, in contrast to the dictator game. The effect of efficiency on provision of the good is only about two thirds of that in the dictator game. The effect of the receiver being the hospice is also positive and significant and not different from that estimated using the dictator game data. The interaction effects of the various treatments are qualitatively similar to those in the dictator games.

In regressions that use the data from the cost dispersion games, we find no support for Conjecture 4 while Conjecture 3 is supported, both in the neutral and the medical framing. As in the dictator games, we find sizable differences in the size and direction of the effect of the Hippocratic Oath on provision of the good between the neutral and the medical framing. The interaction effects of the efficiency of providing the good and the Hippocratic Oath are similar to those in the dictator game.

\section{Conclusion}

In this paper, we studied the impact of professional norms on the behavior of prospective physicians in simple distribution games. Our first experimental manipulation makes the Hippocratic Oath - a professional norm which focuses the physician's treatment choice on the patient's benefit - salient before the games are played. The second manipulation varies the identity of the receivers. The receiver is either another student subject or a real-world charity that cares for patients. The third manipulation contrasts a neutral setting with a framing that provides medical context.

We observe that in the first four games, which are standard dictator games, subjects' behavior does not differ from that usually observed in experimental studies. In particular, subjects have concerns for efficiency. This holds even in the medical framing and if the receiver is a charity that cares for real-world patients. Our novel finding is that the 
salience of professional norms significantly increases subjects' willingness to give up some of their own payoffs for the benefit of another subject, and it reduces the extent to which subjects react to efficiency (but only in the medical framing). We therefore conclude that professional norms mitigate problems of asymmetric information between physicians and patients, but they may also lower societal welfare through increased provision of costly treatments with mild benefits for the patient.

In real life situations, we expect concerns for efficiency to be weaker for several reasons. First, costs to society are often not salient to physicians when they make their treatment choices. Second, while treatment costs may be large, they are usually dispersed among many payers (insurance holders or tax payers). Schumacher et al. (2014) show that decision makers neglect the costs to payers and thus efficiency concerns if the costs of treatment are high but dispersed among many individuals. Peer effects or concerns for social status may induce the physician to dislike providing less treatment than his reference groups of physicians active in the same field (Cooper and Rebitzer, 2002; Kolstad, 2013).

These concerns notwithstanding, our findings support the notion that professional norms affect the way in which physicians perceive the trade-off between the patients' benefits, their own payoffs, and the payments made by the payers. The Hippocratic Oath, which is still the predominant behavioral norm in the medical profession, puts all its emphasis on the patient. While it appears to have the potential of restraining the physician's selfinterest, it does not take into account the costs of the provision of care - too little weight is given to the welfare of those who pay and the opportunity costs of not spending a given health-care budget on other patients. As discussed above, the World Medical Association realizes this tension in its Ethics Manual. An active discussion takes place in the medical ethics literature as well; see, for example, Brett (2012).

Several directions for future research emerge. Using experimental designs such as ours, one might study how professional norms affect behavior in other professions in which some degree of altruism might be socially beneficial. While the Hippocratic Oath might have weaker effects in different populations, there might be other professional norms that are quite relevant for them, as suggested by the study about the effect of social norms on bankers' behavior (Cohn et al., 2014). Finally, coming back to physician behavior, it would also be interesting to study how physician behavior is affected by making salient 
that the budget for medical services is fixed, which implies that treating one patient more expensively implicitly harms another who necessarily will receive less treatment. In fact, the World Medical Association (2009) stresses this trade-off in the current version of its ethics manual, but this is not the professional norm induced by the Hippocratic Oath or the Declaration of Geneva which still prevail. 


\section{References}

Allard, M., Jelovac, I., Léger, P.T., 2011. Treatment and Referral Decisions Under Different Physician Payment Mechanisms. Journal of Health Econonomics, 30(5), 880-893.

American Medical Association, 1996. Code of Medical Ethics. American Medical Association, Chicago, IL.

Andreoni, J., Vesterlund, L., 2001. Which is the Fair Sex? Differences in Altruism. Quarterly Journal of Economics, 116(1), 293-312.

Andreoni, J., Miller, M., 2002. Giving According to GARP: An Experimental Test of the Consistency of Preferences for Altruism. Econometrica, 70(2), 737-753.

Arrow, K., 1963. Uncertainty and the Welfare Economics of Medical Care. American Economic Review, 53, 941-969.

Arrow, K., 1971. Political and Economic Evaluation of Social Effects and Externalities. In Margolis, J. (editor), The Analysis of Public Output, 1-23, Columbia University Press, New York, NY.

Baker, R., McCullough, L.B., 2009. What is the History of Medical Ethics. In Baker, R., McCollough, L.B. (editors), The Cambridge World History of Medical Ethics, 3-15, Cambridge University Press, Cambridge, UK.

Bargh, J.A., Chartrand, T.L., 2000. The Mind in the Middle: A Practical Guide to Priming and Automaticity Research. In Reis, H.T., Judd, C.M. (editors), Handbook of Research Methods in Social and Personality Psychology, 253-285, Cambridge University Press, Cambridge. UK.

Benjamin, D. J., Choi, J. J., Strickland, A.J., 2010. Social Identity and Preferences. American Economic Review, 100, 1913-1928.

Brandts, J., Charness, G., 2011. The Strategy versus the Direct-response Method: a First Survey of Experimental Comparisons. Experimental Economics, 14, 375-398.

Brett, A. S., 2012. Physicians Have a Responsibility to Meet the Health Care Needs of Society. Journal of Law, Medicine and Ethics, 40, 526-531.

Brosig-Koch, J., Hennig-Schmidt, H, Kairies, N., Wiesen, D., 2013. How to Improve Patient Care? An Analysis of Capitation, Fee-for-Service, and Mixed Payment Schemes for Physicians. Ruhr Economic Papers, No. 412. 
Brosig-Koch, J., Hennig-Schmidt, H, Kairies, N., Wiesen, D., 2015a. The Effects of Introducing Mixed Payment Systems for Physicians: Experimental Evidence. Ruhr Economic Papers, No. 543.

Brosig-Koch, J., Hennig-Schmidt, H, Kairies, N., Wiesen, D., 2015b. Using Artefactual Field and Lab Experiments to Investigate how Fee-for-service and Capitation Affect Medical Service Provision. Journal of Economic Behavior and Organization, in press.

Camerer, C., 2003. Behavioral Game Theory: Experiments in Strategic Interaction. Princeton University Press, Princeton, NJ.

Chalkley, M., Malcomson, J.M., 1998. Contracting for Health Services when Patient Demand Does Not Reflect Quality. Journal of Health Econonomics, 17, 1-19.

Chandra, A., Skinner, J., 2012. Technology Growth and Expenditure Growth in Health Care. Journal of Economic Literature, 50(3), 645-680.

Charness, G., Rabin, M., 2002. Understanding Social Preferences with Simple Tests. The Quarterly Journal of Econonomics, 117(3), 817-869.

Choné, P., Ma, C.-t.A., 2011. Optimal Healthcare Contract Under Physician Agency. Annales d'Economie et de Statistique, 101/102, 229-256.

Cohn, A., Marechal, M., Fehr, E., 2014. A Culture of Cheating? Dishonesty and Business Culture in the Banking Industry. Nature, 516, 86-89.

Cooper, D.J., Rebitzer, J.B., 2002. Physician Incentives in Managed Care Organizations: Medical Practice Norms and the Quality of Care. Levy Economics Institute, Public Policy Brief, No. 70.

Crawshaw, R., 1970. The Contemporary Use of Medical Oaths. Journal of Chronic Diseases, 23(3), 145-150.

Croson, R., Gneezy, U., 2009. Gender Differences in Preferences. Journal of Economic Literature, $448-474$

Currie, J. MacLeod, W.B., 2008. First Do No Harm? Tort Reform and Birth Outcomes. Quarterly Journal of Economics, 123(2), 795-830.

Ellis, R.P., McGuire, T., 1986. Provider Behavior under Prospective Reimbursement: Cost Sharing and Supply. Journal of Health Economics, 5, 129-151. 
Engel C., 2011. Dictator Games: A Meta Study. Experimental Economics, 14(4), 583-610.

Engelmann, D., Strobel, M., 2004. Inequality Aversion, Efficiency, and Maximin Preferences in Simple Distribution Experiments. American Economic Review, 94(4), 857-869.

Engelmann, D., Strobel, M., 2007. Preferences Over Income Distributions: Experimental Evidence. Public Finance Review, 35(2), 285-310.

Fisman, R., Kariv, S., Markovits, D., 2007. Individual Preferences for Giving. American Economic Review, 97(5), 1858-1877.

Fisman, R., Jakiela, P., Kariv, S., 2014. The Distributional Preferences of Americans. NBER Working Paper No. 20145.

Fuchs, V.R., (1974). Who Shall Live? Health, Economics and Social Choice. Basic Books, New York, NY.

Godager, G., Wiesen, D., 2013. Profit or Patients' Health Benefit? Exploring the Heterogeneity in Physician Altruism. Journal of Health Economics, 32(6), 1105-1116.

Hennig-Schmidt, H., Selten, R., Wiesen, D., 2014. How Payment Systems Affect Physicians' Provision Behavior: An Experimental Investigation. Journal of Health Economics, 30(4), 637-646.

Hennig-Schmidt, H., Wiesen, D., 2011. Other-regarding Behavior and Motivation in Health Care Provision: An Experiment with Medical and Non-medical Students. Social Science and Medicine, 108, 156-165.

Hulkower, R., 2010. The History of the Hippocratic Oath: Outdated, Inauthentic, and Yet Still Relevant. The Einstein Journal of Biology and Medicine, 25(1), 41-44.

Kerschbamer, R. 2015. The Geometry of Distributional Preferences and a Non-Parametric Identification Approach. European Economic Review, 76, 85-103.

Kolstad, J.T., 2013. Information and Quality when Motivation is Intrinsic: Evidence from Surgeon Report Cards. American Economic Review, 103(7), 2875-2910.

Liu, T., Ma, C.-t.A., 2013. Health Insurance, Treatment Plan, and Delegation to Altruistic Physician. Journal of Economic Behavior and Organization, 85, 79-96.

Macer, D.R.J., 1990. Shaping Genes: Ethics, Law and Science of Using New Genetic Technology in Medicine and Agriculture. Eubios Ethics Institute, Christchurch. 
Miles, S.H., 2005. The Hippocratic Oath and the Ethics of Medicine. Oxford University Press.

McGuire, T.G., 2000. Physician Agency. In Culyer, A.j., Newhouse, J.P. (editors), Handbook of Health Economics, Volume 1A, 461-536, Elsevier, Amsterdam.

Messner, K.D. , Poe, G.L., Rondeau, D., Schulze, W.D., Vossler, C.A., 2012. Social Preference and Voting. An Exploration Using a Novel Preference Revealing Mechanism. Journal of Public Economics, 94(3-4), 308-317.

Orr, R.D., Pang, N., Pellegrino, E.D., Siegler, M., 1997. Use of the Hippocratic Oath: A Review of Twentieth Century Practice and a Content Analysis of Oaths Administered in Medical Schools in the U.S. and Canada in 1993. Joural of Clinical Ethics, 8(4), 377-388.

Schildberg-Hoerisch, H., 2010. Is the Veil of Ignorance Only a Concept About Risk? An Experiment. Journal of Public Economics, 94(11-12), 1062-1066.

Schumacher, H., Kesternich, I., Kosfeld, M., Winter, J., 2014. Us and Them: Distributional Preferences in Small and Large Groups. Discussion Paper No. 453, Sonderforschungsbereich/TR 15, University of Munich.

Smith, L., 2008. A Brief History of Medicine's Hippocratic Oath, or How Times Have Changed. Otolaryngology-Head and Neck Surgery, 139(1), 1-4.

Sohl, P., Bassford, H.A., 1986. Codes of Medical Ethics: Traditional Foundations and Contemporary Practice. Social Science and Medicine, 22(11), 1175-1179.

Sulmasy, D.P., 1999. What is an Oath and Why Should a Physician Swear One? Theoretical Medicine and Bioethics, 20(4), 329-346.

World Medical Association, 2009. Medical Ethics Manual. World Medical Association. 


\section{Tables and figures}

Table 1: Design of the experiment (tokens per unit provided by the decider)

\begin{tabular}{|c|c|c|c|c|}
\hline Game & $\begin{array}{c}\text { Decider benefit } \\
\qquad a \\
\end{array}$ & $\begin{array}{c}\text { Receiver benefit } \\
b \\
\end{array}$ & $\begin{array}{c}\text { Cost per payer } \\
c \\
\end{array}$ & $\begin{array}{c}\text { Group payoff } \\
a+b-3 c\end{array}$ \\
\hline \multicolumn{5}{|c|}{ Dictator games } \\
\hline 1 & -1.0 & 1.5 & 0.0 & 0.5 \\
\hline 2 & -1.0 & 1.0 & 0.0 & 0.0 \\
\hline 3 & -1.0 & 0.5 & 0.0 & -0.5 \\
\hline 4 & -1.0 & 0.2 & 0.0 & -0.8 \\
\hline \multicolumn{5}{|c|}{ Interested cost dispersion games } \\
\hline 5 & 1.0 & 1.5 & 1.0 & -0.5 \\
\hline 6 & 1.0 & 1.0 & 1.0 & -1.0 \\
\hline 7 & 1.0 & 0.5 & 1.0 & -1.5 \\
\hline 8 & 1.0 & 0.2 & 1.0 & -1.8 \\
\hline \multicolumn{5}{|c|}{ Disinterested cost dispersion games } \\
\hline 9 & 0.0 & 1.5 & 1.0 & -1.5 \\
\hline 10 & 0.0 & 1.0 & 1.0 & -2.0 \\
\hline 11 & 0.0 & 0.5 & 1.0 & -2.5 \\
\hline 12 & 0.0 & 0.2 & 1.0 & -2.8 \\
\hline
\end{tabular}


Table 2: Number of subjects randomly assigned to the eight treatments

\begin{tabular}{|c|c|c|c|c|c|c|c|}
\hline \multicolumn{4}{|c|}{ Hospice receiver } & \multicolumn{4}{|c|}{ Student receiver } \\
\hline \multicolumn{2}{|c|}{ No oath } & \multicolumn{2}{|c|}{ Oath } & \multicolumn{2}{|c|}{ No oath } & \multicolumn{2}{|c|}{ Oath } \\
\hline $\begin{array}{l}\text { Neutral } \\
\text { framing }\end{array}$ & $\begin{array}{l}\text { Medical } \\
\text { framing }\end{array}$ & $\begin{array}{l}\text { Neutral } \\
\text { framing }\end{array}$ & $\begin{array}{l}\text { Medical } \\
\text { framing }\end{array}$ & $\begin{array}{l}\text { Neutral } \\
\text { framing }\end{array}$ & $\begin{array}{l}\text { Medical } \\
\text { framing }\end{array}$ & $\begin{array}{l}\text { Neutral } \\
\text { framing }\end{array}$ & $\begin{array}{l}\text { Medical } \\
\text { framing }\end{array}$ \\
\hline 37 & 33 & 32 & 41 & 28 & 25 & 34 & 36 \\
\hline
\end{tabular}


Table 3: Average number of units provided, by professional norm manipulation

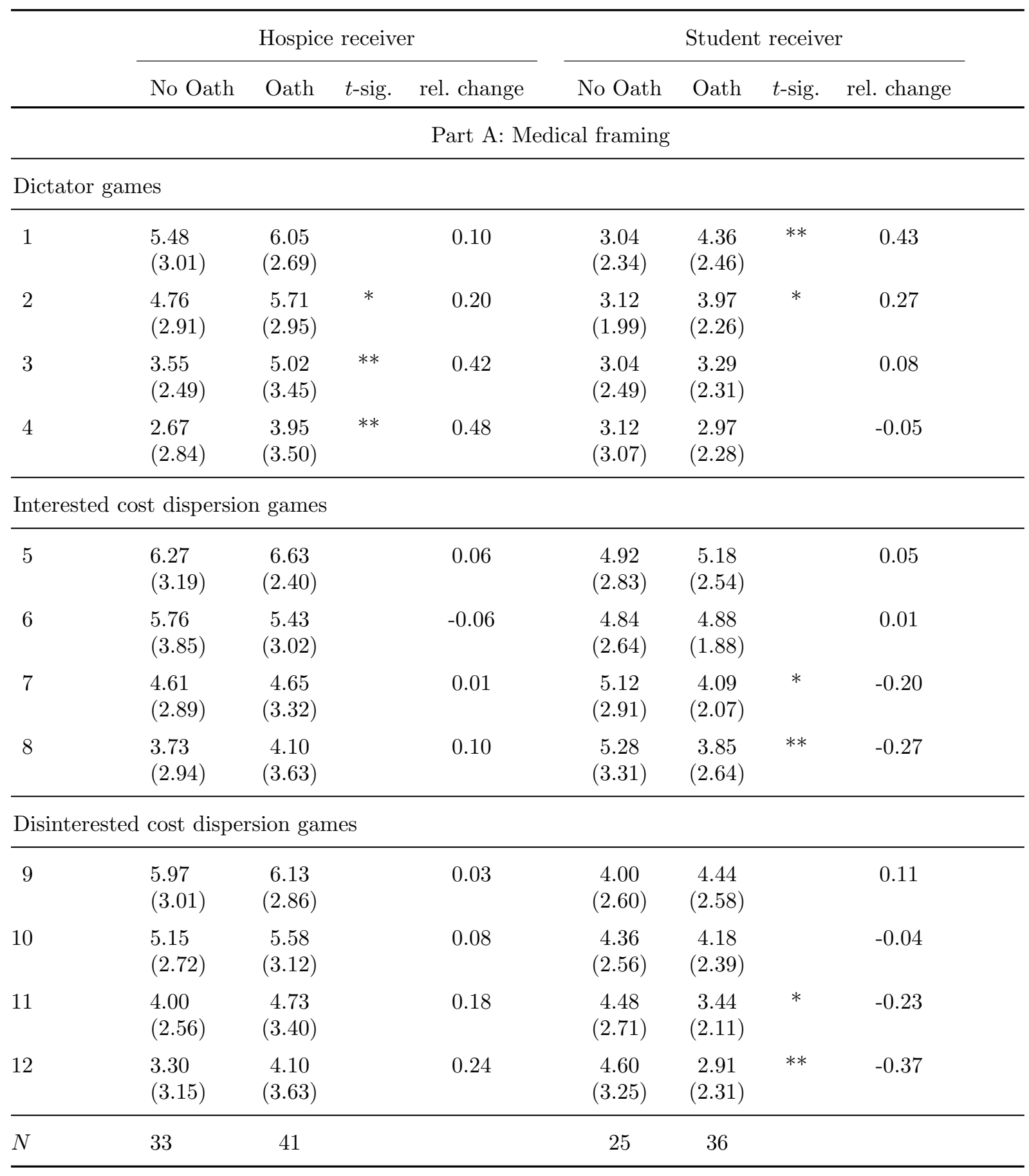

Notes: One-sided $t$-tests for differences in means; ${ }^{* *} p<0.01,{ }^{* *} p<0.05,{ }^{*} p<0.1$. 
Table 3: continued

\begin{tabular}{|c|c|c|c|c|c|c|c|c|}
\hline & \multicolumn{4}{|c|}{ Hospice receiver } & \multicolumn{4}{|c|}{ Student receiver } \\
\hline & No Oath & Oath & $t$-sig. & rel. change & No Oath & Oath & $t$-sig. & rel. change \\
\hline & \multicolumn{8}{|c|}{ Part B: Neutral framing } \\
\hline \multicolumn{9}{|c|}{ Dictator games } \\
\hline 1 & $\begin{array}{l}5.84 \\
(3.56)\end{array}$ & $\begin{array}{c}6.19 \\
(3.50)\end{array}$ & & 0.06 & $\begin{array}{c}4.57 \\
(3.51)\end{array}$ & $\begin{array}{c}4.24 \\
(3.54)\end{array}$ & & -0.07 \\
\hline 2 & $\begin{array}{l}5.97 \\
(3.61)\end{array}$ & $\begin{array}{c}5.22 \\
(3.62)\end{array}$ & & -0.13 & $\begin{array}{c}3.39 \\
(2.64)\end{array}$ & $\begin{array}{c}2.82 \\
(2.72)\end{array}$ & & -0.17 \\
\hline 3 & $\begin{array}{l}4.84 \\
(3.95)\end{array}$ & $\begin{array}{c}4.22 \\
(3.90)\end{array}$ & & -0.13 & $\begin{array}{c}2.86 \\
(2.81)\end{array}$ & $\begin{array}{c}1.38 \\
(2.13)\end{array}$ & $* *$ & -0.52 \\
\hline 4 & $\begin{array}{l}4.16 \\
(3.93)\end{array}$ & $\begin{array}{c}2.91 \\
(3.56)\end{array}$ & $*$ & -0.30 & $\begin{array}{c}1.79 \\
(3.05)\end{array}$ & $\begin{array}{c}1.38 \\
(2.61)\end{array}$ & & -0.23 \\
\hline \multicolumn{9}{|c|}{ Interested cost dispersion games } \\
\hline 5 & $\begin{array}{l}6.73 \\
(3.00)\end{array}$ & $\begin{array}{c}6.59 \\
(2.63)\end{array}$ & & -0.02 & $\begin{array}{c}4.07 \\
(2.18)\end{array}$ & $\begin{array}{c}4.62 \\
(3.45)\end{array}$ & & 0.13 \\
\hline 6 & $\begin{array}{l}6.11 \\
(3.14)\end{array}$ & $\begin{array}{c}5.69 \\
(2.87)\end{array}$ & & -0.07 & $\begin{array}{c}4.43 \\
(2.25)\end{array}$ & $\begin{array}{c}4.74 \\
(3.81)\end{array}$ & & 0.07 \\
\hline 7 & $\begin{array}{l}5.32 \\
(3.57)\end{array}$ & $\begin{array}{c}4.47 \\
(3.20)\end{array}$ & & -0.16 & $\begin{array}{c}4.50 \\
(2.77)\end{array}$ & $\begin{array}{c}4.65 \\
(4.04)\end{array}$ & & 0.03 \\
\hline 8 & $\begin{array}{l}4.68 \\
(3.90)\end{array}$ & $\begin{array}{c}4.22 \\
(3.81)\end{array}$ & & -0.10 & $\begin{array}{c}3.57 \\
(2.97)\end{array}$ & $\begin{array}{c}4.00 \\
(4.13)\end{array}$ & & 0.12 \\
\hline \multicolumn{9}{|c|}{ Disinterested cost dispersion games } \\
\hline 9 & $\begin{array}{l}6.81 \\
(3.14)\end{array}$ & $\begin{array}{c}5.78 \\
(2.63)\end{array}$ & * & -0.15 & $\begin{array}{c}3.57 \\
(2.25)\end{array}$ & $\begin{array}{c}3.18 \\
(2.65)\end{array}$ & & -0.11 \\
\hline 10 & $\begin{array}{l}5.92 \\
(3.36)\end{array}$ & $\begin{array}{c}5.00 \\
(2.63)\end{array}$ & & -0.16 & $\begin{array}{c}3.75 \\
(2.58)\end{array}$ & $\begin{array}{c}2.59 \\
(2.64)\end{array}$ & $* *$ & -0.31 \\
\hline 11 & $\begin{array}{l}5.38 \\
(3.53)\end{array}$ & $\begin{array}{c}4.09 \\
(3.26)\end{array}$ & $*$ & -0.24 & $\begin{array}{c}3.39 \\
(3.08)\end{array}$ & $\begin{array}{c}2.21 \\
(2.85)\end{array}$ & $*$ & -0.35 \\
\hline 12 & $\begin{array}{l}4.51 \\
(3.93)\end{array}$ & $\begin{array}{c}3.25 \\
(3.44)\end{array}$ & $*$ & -0.28 & $\begin{array}{c}2.75 \\
(3.46)\end{array}$ & $\begin{array}{c}1.74 \\
(3.17)\end{array}$ & & -0.37 \\
\hline$N$ & 37 & 32 & & & 28 & 34 & & \\
\hline
\end{tabular}

Notes: One-sided $t$-tests for differences in means; ${ }^{* * *} p<0.01,{ }^{* *} p<0.05,{ }^{*} p<0.1$. 
Table 4: Average number of units provided, by receiver manipulation

\begin{tabular}{|c|c|c|c|c|c|c|c|c|}
\hline & \multicolumn{4}{|c|}{ No oath } & \multicolumn{4}{|c|}{ Oath } \\
\hline & Student & Hospice & $t$-sig. & rel. change & Student & Hospice & $t$-sig. & rel. change \\
\hline & \multicolumn{8}{|c|}{ Part A: Medical framing } \\
\hline \multicolumn{9}{|c|}{ Dictator games } \\
\hline 1 & $\begin{array}{l}3.04 \\
(2.34)\end{array}$ & $\begin{array}{c}5.48 \\
(3.01)\end{array}$ & $* * *$ & 0.80 & $\begin{array}{c}4.36 \\
(2.46)\end{array}$ & $\begin{array}{c}6.05 \\
(2.69)\end{array}$ & $* * *$ & 0.39 \\
\hline 2 & $\begin{array}{l}3.12 \\
(1.99)\end{array}$ & $\begin{array}{c}4.76 \\
(2.91)\end{array}$ & $* * *$ & 0.53 & $\begin{array}{c}3.97 \\
(2.26)\end{array}$ & $\begin{array}{c}5.70 \\
(2.95)\end{array}$ & $* * *$ & 0.44 \\
\hline 3 & $\begin{array}{l}3.04 \\
(2.46)\end{array}$ & $\begin{array}{c}3.55 \\
(2.49)\end{array}$ & & 0.17 & $\begin{array}{c}3.29 \\
(2.31)\end{array}$ & $\begin{array}{c}5.02 \\
(3.45)\end{array}$ & $* * *$ & 0.53 \\
\hline 4 & $\begin{array}{l}3.12 \\
(3.07)\end{array}$ & $\begin{array}{c}2.67 \\
(2.84)\end{array}$ & & -0.14 & $\begin{array}{c}2.97 \\
(2.28)\end{array}$ & $\begin{array}{c}3.95 \\
(3.50)\end{array}$ & $*$ & 0.33 \\
\hline \multicolumn{9}{|c|}{ Interested cost dispersion games } \\
\hline 5 & $\begin{array}{l}4.92 \\
(2.83)\end{array}$ & $\begin{array}{c}6.27 \\
(3.19)\end{array}$ & $* *$ & 0.27 & $\begin{array}{c}5.18 \\
(2.54)\end{array}$ & $\begin{array}{c}6.63 \\
(2.40)\end{array}$ & $* * *$ & 0.28 \\
\hline 6 & $\begin{array}{l}4.84 \\
(2.64)\end{array}$ & $\begin{array}{c}5.76 \\
(2.85)\end{array}$ & & 0.19 & $\begin{array}{c}4.88 \\
(1.88)\end{array}$ & $\begin{array}{c}5.43 \\
(3.02)\end{array}$ & & 0.11 \\
\hline 7 & $\begin{array}{l}5.12 \\
(2.91)\end{array}$ & $\begin{array}{c}4.61 \\
(2.89)\end{array}$ & & -0.10 & $\begin{array}{c}4.09 \\
(2.07)\end{array}$ & $\begin{array}{c}4.65 \\
(3.32)\end{array}$ & & 0.14 \\
\hline 8 & $\begin{array}{l}5.28 \\
(3.31)\end{array}$ & $\begin{array}{c}3.73 \\
(2.94)\end{array}$ & $* *$ & -0.29 & $\begin{array}{c}3.85 \\
(2.64)\end{array}$ & $\begin{array}{c}4.10 \\
(3.63)\end{array}$ & & 0.06 \\
\hline \multicolumn{9}{|c|}{ Disinterested cost dispersion games } \\
\hline 9 & $\begin{array}{l}4.00 \\
(2.60)\end{array}$ & $\begin{array}{c}5.97 \\
(3.01)\end{array}$ & $* * *$ & 0.49 & $\begin{array}{c}4.44 \\
(2.58)\end{array}$ & $\begin{array}{c}6.13 \\
(2.86)\end{array}$ & $* * *$ & 0.38 \\
\hline 10 & $\begin{array}{l}4.36 \\
(2.56)\end{array}$ & $\begin{array}{c}5.15 \\
(2.72)\end{array}$ & & 0.18 & $\begin{array}{c}4.18 \\
(2.39)\end{array}$ & $\begin{array}{c}5.58 \\
(3.12)\end{array}$ & $* *$ & 0.34 \\
\hline 11 & $\begin{array}{l}4.48 \\
(2.71)\end{array}$ & $\begin{array}{c}4.00 \\
(2.56)\end{array}$ & & -0.11 & $\begin{array}{c}3.44 \\
(2.11)\end{array}$ & $\begin{array}{c}4.73 \\
(3.40)\end{array}$ & $* *$ & 0.37 \\
\hline 12 & $\begin{array}{l}4.60 \\
(3.25)\end{array}$ & $\begin{array}{c}3.30 \\
(3.15)\end{array}$ & $*$ & -0.28 & $\begin{array}{c}2.91 \\
(2.31)\end{array}$ & $\begin{array}{c}4.10 \\
(3.63)\end{array}$ & $*$ & 0.41 \\
\hline$N$ & 25 & 33 & & & 36 & 41 & & \\
\hline
\end{tabular}

Notes: One-sided $t$-tests for differences in means; ${ }^{* * *} p<0.01,{ }^{* *} p<0.05,{ }^{*} p<0.1$. 
Table 4: continued

\begin{tabular}{|c|c|c|c|c|c|c|c|c|}
\hline & \multicolumn{4}{|c|}{ No oath } & \multicolumn{4}{|c|}{ Oath } \\
\hline & Student & Hospice & $t$-sig. & rel. change & Student & Hospice & $t$-sig. & rel. change \\
\hline & \multicolumn{8}{|c|}{ Part B: Neutral framing } \\
\hline \multicolumn{9}{|c|}{ Dictator games } \\
\hline 1 & $\begin{array}{l}4.57 \\
(3.51)\end{array}$ & $\begin{array}{c}5.84 \\
(3.56)\end{array}$ & $*$ & 0.28 & $\begin{array}{c}4.24 \\
(3.54)\end{array}$ & $\begin{array}{c}6.19 \\
(3.50)\end{array}$ & $* *$ & 0.46 \\
\hline 2 & $\begin{array}{l}3.39 \\
(2.64)\end{array}$ & $\begin{array}{c}5.97 \\
(3.61)\end{array}$ & $* * *$ & 0.76 & $\begin{array}{c}2.82 \\
(2.72)\end{array}$ & $\begin{array}{c}5.22 \\
(3.62)\end{array}$ & $* * *$ & 0.85 \\
\hline 3 & $\begin{array}{l}2.86 \\
(2.81)\end{array}$ & $\begin{array}{c}4.84 \\
(3.95)\end{array}$ & $* *$ & 0.69 & $\begin{array}{c}1.38 \\
(2.13)\end{array}$ & $\begin{array}{c}4.22 \\
(3.90)\end{array}$ & $* * *$ & 2.05 \\
\hline 4 & $\begin{array}{l}1.79 \\
(3.05)\end{array}$ & $\begin{array}{c}4.16 \\
(3.93)\end{array}$ & $* *$ & 1.33 & $\begin{array}{c}1.38 \\
(2.61)\end{array}$ & $\begin{array}{c}2.91 \\
(3.56)\end{array}$ & $* *$ & 1.10 \\
\hline \multicolumn{9}{|c|}{ Interested cost dispersion games } \\
\hline 5 & $\begin{array}{l}4.07 \\
(2.18)\end{array}$ & $\begin{array}{c}6.73 \\
(3.00)\end{array}$ & $* * *$ & 0.65 & $\begin{array}{c}4.62 \\
(3.45)\end{array}$ & $\begin{array}{c}6.59 \\
(2.63)\end{array}$ & $* * *$ & 0.43 \\
\hline 6 & $\begin{array}{l}4.43 \\
(2.25)\end{array}$ & $\begin{array}{c}6.11 \\
(3.14)\end{array}$ & $* * *$ & 0.38 & $\begin{array}{c}4.74 \\
(3.81)\end{array}$ & $\begin{array}{c}5.69 \\
(2.87)\end{array}$ & & 0.20 \\
\hline 7 & $\begin{array}{l}4.50 \\
(2.77)\end{array}$ & $\begin{array}{c}5.32 \\
(3.57)\end{array}$ & & 0.18 & $\begin{array}{c}4.65 \\
(4.04)\end{array}$ & $\begin{array}{c}4.47 \\
(3.20)\end{array}$ & & -0.04 \\
\hline 8 & $\begin{array}{l}3.57 \\
(2.97)\end{array}$ & $\begin{array}{c}4.68 \\
(3.90)\end{array}$ & & 0.31 & $\begin{array}{c}4.00 \\
(4.13)\end{array}$ & $\begin{array}{c}4.22 \\
(3.81)\end{array}$ & & 0.05 \\
\hline \multicolumn{9}{|c|}{ Disinterested cost dispersion games } \\
\hline 9 & $\begin{array}{l}3.57 \\
(2.25)\end{array}$ & $\begin{array}{c}6.81 \\
(3.14)\end{array}$ & $* * *$ & 0.91 & $\begin{array}{c}3.18 \\
(2.65)\end{array}$ & $\begin{array}{c}5.78 \\
(2.64)\end{array}$ & $* * *$ & 0.82 \\
\hline 10 & $\begin{array}{l}3.75 \\
(2.58)\end{array}$ & $\begin{array}{c}5.92 \\
(3.36)\end{array}$ & $* * *$ & 0.58 & $\begin{array}{c}2.59 \\
(2.64)\end{array}$ & $\begin{array}{c}5.00 \\
(2.63)\end{array}$ & $* * *$ & 0.93 \\
\hline 11 & $\begin{array}{l}3.39 \\
(3.08)\end{array}$ & $\begin{array}{c}5.38 \\
(3.53)\end{array}$ & $* *$ & 0.59 & $\begin{array}{c}2.21 \\
(2.86)\end{array}$ & $\begin{array}{c}4.09 \\
(3.26)\end{array}$ & $* * *$ & 0.86 \\
\hline 12 & $\begin{array}{l}2.75 \\
(3.46)\end{array}$ & $\begin{array}{c}4.51 \\
(3.93)\end{array}$ & $* *$ & 0.64 & $\begin{array}{c}1.74 \\
(3.17)\end{array}$ & $\begin{array}{c}3.25 \\
(3.44)\end{array}$ & $* *$ & 0.87 \\
\hline$N$ & 28 & 37 & & & 34 & 32 & & \\
\hline
\end{tabular}

Notes: One-sided $t$-tests for differences in means; ${ }^{* * *} p<0.01,{ }^{* *} p<0.05,{ }^{*} p<0.1$. 
Table 5: Regressions predicting units provided in the dictator games (games 1-4)

\begin{tabular}{|c|c|c|c|c|}
\hline Explanatory variable & $(1)$ & $(2)$ & $(3)$ & $(4)$ \\
\hline \multirow[t]{2}{*}{ Efficiency } & $1.642^{* * *}$ & $1.640^{* * *}$ & $1.397^{* * *}$ & $1.254^{* * *}$ \\
\hline & {$[0.174]$} & {$[0.174]$} & {$[0.372]$} & {$[0.198]$} \\
\hline \multirow[t]{2}{*}{ Medical Framing } & 0.160 & -0.122 & 0.013 & -0.264 \\
\hline & {$[0.316]$} & {$[0.541]$} & {$[0.319]$} & [0.433] \\
\hline \multirow[t]{2}{*}{ Hospice Receiver } & $1.718^{* * *}$ & $1.921^{* * *}$ & $1.712^{* * *}$ & $1.438^{* * *}$ \\
\hline & {$[0.314]$} & {$[0.586]$} & {$[0.313]$} & {$[0.417]$} \\
\hline \multirow[t]{2}{*}{ Hippocratic Oath is shown } & 0.094 & -0.807 & 0.180 & 0.240 \\
\hline & {$[0.320]$} & {$[0.514]$} & {$[0.323]$} & {$[0.429]$} \\
\hline \multirow[t]{2}{*}{ Medical Framing * Hippocratic Oath } & & $1.390^{* *}$ & & \\
\hline & & {$[0.638]$} & & \\
\hline \multirow[t]{2}{*}{ Hospice Receiver $*$ Hippocratic Oath } & & 0.397 & & \\
\hline & & {$[0.625]$} & & \\
\hline \multirow[t]{2}{*}{ Hospice Receiver $*$ Medical Framing } & & -0.864 & & \\
\hline & & {$[0.618]$} & & \\
\hline \multirow[t]{2}{*}{ Efficiency $*$ Hippocratic Oath } & & & $1.206^{* *}$ & \\
\hline & & & {$[0.533]$} & \\
\hline \multirow[t]{2}{*}{ Efficiency $*$ Medical Framing } & & & 0.087 & \\
\hline & & & {$[0.560]$} & \\
\hline \multirow[t]{2}{*}{ Efficiency $*$ Hippocratic Oath * Medical Framing } & & & $-1.550^{* *}$ & \\
\hline & & & {$[0.767]$} & \\
\hline \multirow[t]{2}{*}{ Male } & & & & -1.076 \\
\hline & & & & {$[0.657]$} \\
\hline \multirow[t]{2}{*}{ Efficiency $*$ Male } & & & & $0.968 * * *$ \\
\hline & & & & {$[0.367]$} \\
\hline \multirow[t]{2}{*}{ Medical Framing * Male } & & & & 0.823 \\
\hline & & & & {$[0.657]$} \\
\hline \multirow[t]{2}{*}{ Hospice Receiver * Male } & & & & 0.604 \\
\hline & & & & {$[0.638]$} \\
\hline \multirow[t]{2}{*}{ Hippocratic Oath * Male } & & & & -0.108 \\
\hline & & & & {$[0.662]$} \\
\hline \multirow[t]{2}{*}{ Sequence1 } & -0.445 & -0.466 & -0.447 & -0.480 \\
\hline & {$[0.456]$} & {$[0.449]$} & {$[0.455]$} & {$[0.457]$} \\
\hline \multirow[t]{2}{*}{ Sequence2 } & -0.258 & -0.247 & -0.255 & -0.294 \\
\hline & {$[0.498]$} & {$[0.500]$} & {$[0.497]$} & {$[0.496]$} \\
\hline \multirow[t]{2}{*}{ Sequence 4} & 0.215 & 0.179 & 0.199 & 0.148 \\
\hline & {$[0.428]$} & {$[0.424]$} & {$[0.426]$} & {$[0.445]$} \\
\hline \multirow[t]{2}{*}{ Constant } & $3.389^{* * *}$ & $3.651^{* * *}$ & $3.425 * * *$ & $3.894^{* * *}$ \\
\hline & {$[0.438]$} & {$[0.505]$} & {$[0.439]$} & {$[0.560]$} \\
\hline Observations & 1,060 & 1,060 & 1,060 & 1,060 \\
\hline$R$-squared & 0.136 & 0.153 & 0.144 & 0.155 \\
\hline$F$-test sequence dummies ( $p$-value) & 0.416 & 0.419 & 0.433 & 0.440 \\
\hline
\end{tabular}

Notes: Robust standard errors in brackets, clustered by subject, ${ }^{* * *} \mathrm{p}<0.01,{ }^{* *} \mathrm{p}<0.05,{ }^{*} \mathrm{p}<0.1$ 
Table 6: Regressions predicting units provided in the cost dispersion games (games 5-12)

\begin{tabular}{|c|c|c|c|c|c|c|}
\hline \multirow[b]{2}{*}{ Explanatory variable } & \multicolumn{3}{|c|}{$\begin{array}{l}\text { Interested cost } \\
\text { dispersion games }\end{array}$} & \multicolumn{3}{|c|}{$\begin{array}{l}\text { Disinterested cost } \\
\text { dispersion games }\end{array}$} \\
\hline & $(1)$ & $(2)$ & $(3)$ & $(4)$ & $(5)$ & $(6)$ \\
\hline \multirow[t]{2}{*}{ Efficiency } & $1.178^{* * *}$ & $1.179^{* * *}$ & $0.912^{* * *}$ & $1.274^{* * *}$ & $1.274^{* * *}$ & $1.045^{* * *}$ \\
\hline & {$[0.154]$} & {$[0.154]$} & {$[0.284]$} & {$[0.154]$} & {$[0.154]$} & {$[0.294]$} \\
\hline \multirow[t]{2}{*}{ Medical Framing } & 0.002 & 0.419 & 0.252 & 0.416 & 0.569 & 0.099 \\
\hline & {$[0.339]$} & {$[0.585]$} & {$[0.443]$} & {$[0.321]$} & {$[0.575]$} & {$[0.685]$} \\
\hline \multirow[t]{2}{*}{ Hospice Receiver } & $0.791^{* *}$ & $1.230^{* *}$ & $0.792^{* *}$ & $1.571^{* * *}$ & $2.019^{* * *}$ & $1.557^{* * *}$ \\
\hline & {$[0.334]$} & {$[0.572]$} & {$[0.332]$} & {$[0.319]$} & {$[0.577]$} & {$[0.316]$} \\
\hline \multirow[t]{2}{*}{ Hippocratic Oath is Shown } & -0.128 & -0.006 & 0.279 & -0.511 & $-1.231^{* *}$ & 0.224 \\
\hline & {$[0.334]$} & {$[0.612]$} & {$[0.441]$} & {$[0.324]$} & {$[0.542]$} & {$[0.692]$} \\
\hline \multirow[t]{2}{*}{ Medical Framing * Hippocratic Oath } & & -0.056 & & & $1.063^{*}$ & \\
\hline & & {$[0.675]$} & & & {$[0.639]$} & \\
\hline \multirow[t]{2}{*}{ Hospice Receiver $*$ Hippocratic Oath } & & -0.152 & & & 0.387 & \\
\hline & & {$[0.673]$} & & & {$[0.640]$} & \\
\hline \multirow[t]{2}{*}{ Hospice Receiver $*$ Medical Framing } & & -0.714 & & & $-1.340^{* *}$ & \\
\hline & & {$[0.672]$} & & & {$[0.628]$} & \\
\hline \multirow[t]{2}{*}{ Efficiency $*$ Hippocratic Oath } & & & 0.303 & & & $0.580^{*}$ \\
\hline & & & {$[0.417]$} & & & {$[0.347]$} \\
\hline \multirow{2}{*}{ Efficiency $*$ Medical Framing } & & & 0.169 & & & 0.118 \\
\hline & & & {$[0.399]$} & & & {$[0.349]$} \\
\hline \multirow[t]{2}{*}{ Efficiency $*$ Hippocratic Oath * Medical Framing } & & & 0.072 & & & $-0.494^{*}$ \\
\hline & & & {$[0.510]$} & & & {$[0.286]$} \\
\hline \multirow[t]{2}{*}{ Sequence 1} & -0.059 & -0.070 & -0.058 & -0.072 & -0.106 & -0.085 \\
\hline & {$[0.503]$} & {$[0.505]$} & {$[0.504]$} & {$[0.481]$} & {$[0.482]$} & {$[0.481]$} \\
\hline \multirow[t]{2}{*}{ Sequence 2} & -0.189 & -0.212 & -0.189 & -0.635 & -0.647 & -0.628 \\
\hline & {$[0.493]$} & {$[0.497]$} & {$[0.494]$} & {$[0.469]$} & {$[0.472]$} & {$[0.466]$} \\
\hline \multirow[t]{2}{*}{ Sequence 4} & -0.333 & -0.335 & -0.328 & -0.431 & -0.457 & -0.490 \\
\hline & {$[0.446]$} & {$[0.445]$} & {$[0.450]$} & {$[0.429]$} & {$[0.428]$} & {$[0.425]$} \\
\hline \multirow[t]{2}{*}{ Constant } & $6.172^{* * *}$ & $5.927 * * *$ & $5.829 * * *$ & $6.599 * * *$ & $6.650 * * *$ & $6.394^{* * *}$ \\
\hline & {$[0.508]$} & {$[0.531]$} & {$[0.526]$} & {$[0.537]$} & {$[0.572]$} & {$[0.706]$} \\
\hline Observations & 1,050 & 1,050 & 1,050 & 1,052 & 1,052 & 1,052 \\
\hline$R$-squared & 0.051 & 0.055 & 0.052 & 0.119 & 0.139 & 0.127 \\
\hline$F$-test sequence dummies ( $p$-value) & 0.88 & 0.88 & 0.89 & 0.48 & 0.48 & 0.45 \\
\hline
\end{tabular}

Notes: Robust standard errors in brackets, clustered by subject, ${ }^{* * *} \mathrm{p}<0.01,{ }^{* *} \mathrm{p}<0.05,{ }^{*} \mathrm{p}<0.1$ 
Figure 1: Mean payoffs in the dictator games in the medical framing \& charity receiver treatment, by professional norm manipulation

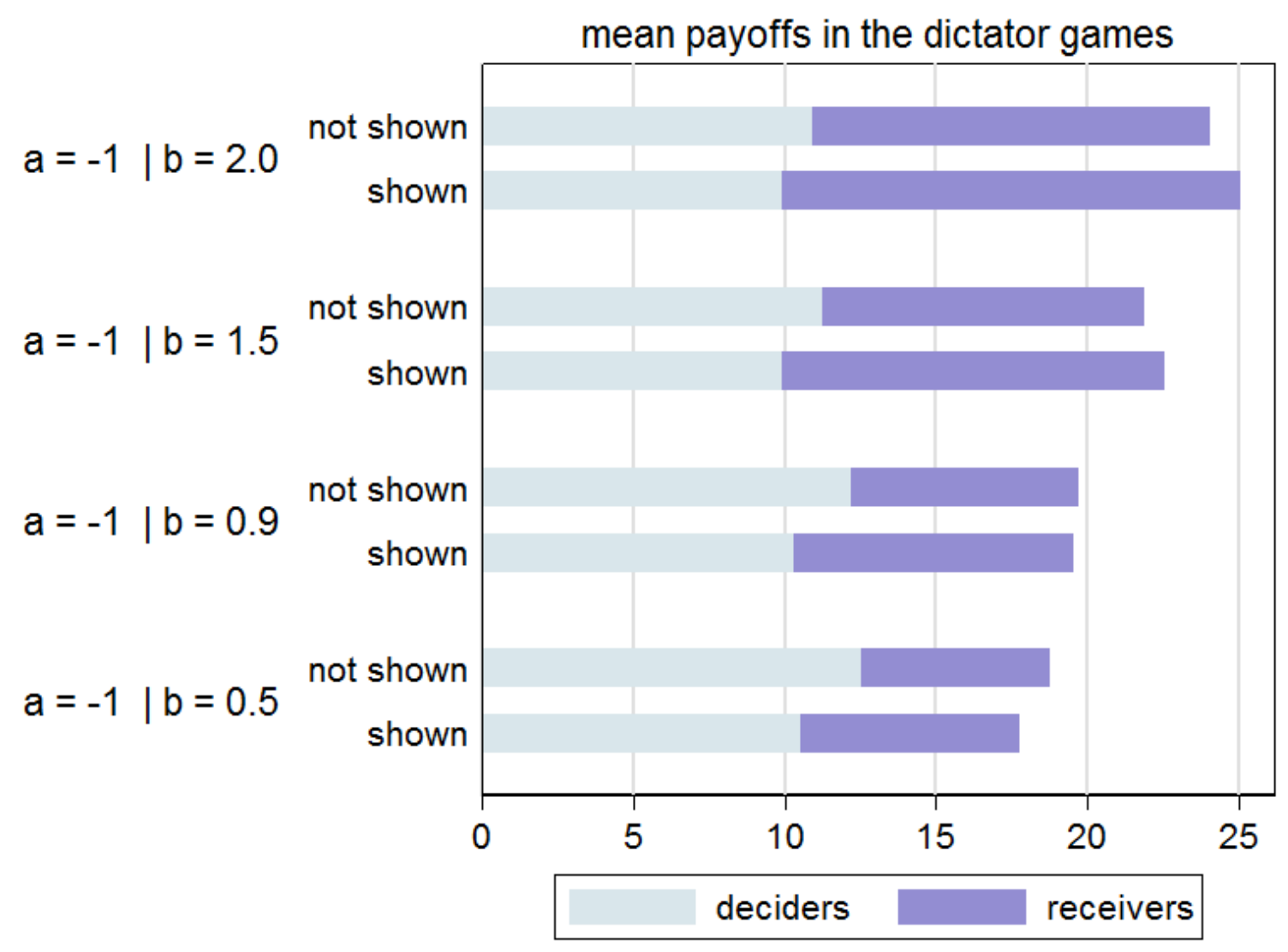


Table A.1: Tobit regressions predicting units provided in the dictator games (games 1-4)

\begin{tabular}{|c|c|c|c|c|}
\hline Explanatory variable & $(1)$ & $(2)$ & $(3)$ & $(4)$ \\
\hline \multirow[t]{2}{*}{ Efficiency } & $2.624^{* * *}$ & $2.622^{* * *}$ & $2.481 * * *$ & $1.921^{* * *}$ \\
\hline & {$[0.292]$} & {$[0.292]$} & {$[0.614]$} & {$[0.295]$} \\
\hline \multirow[t]{2}{*}{ Medical Framing } & 0.579 & 0.571 & 0.296 & -0.095 \\
\hline & {$[0.486]$} & {$[0.837]$} & {$[0.482]$} & {$[0.626]$} \\
\hline \multirow[t]{2}{*}{ Hospice Receiver } & $2.562^{* * *}$ & $3.212^{* * *}$ & $2.562^{* * *}$ & $2.041^{* * *}$ \\
\hline & {$[0.493]$} & {$[0.926]$} & {$[0.492]$} & {$[0.599]$} \\
\hline \multirow[t]{2}{*}{ Hippocratic Oath is shown } & 0.093 & -1.135 & 0.189 & 0.246 \\
\hline & {$[0.487]$} & {$[0.848]$} & {$[0.482]$} & {$[0.611]$} \\
\hline \multirow[t]{2}{*}{ Medical Framing * Hippocratic Oath } & & $1.852^{*}$ & & \\
\hline & & {$[0.975]$} & & \\
\hline \multirow[t]{2}{*}{ Hospice Receiver $*$ Hippocratic Oath } & & 0.507 & & \\
\hline & & {$[0.951]$} & & \\
\hline \multirow[t]{2}{*}{ Hospice Receiver * Medical Framing } & & $-1.812^{*}$ & & \\
\hline & & {$[0.953]$} & & \\
\hline \multirow[t]{2}{*}{ Efficiency $*$ Hippocratic Oath } & & & $1.842^{* *}$ & \\
\hline & & & {$[0.903]$} & \\
\hline \multirow[t]{2}{*}{ Efficiency $*$ Medical Framing } & & & -0.197 & \\
\hline & & & {$[0.873]$} & \\
\hline \multirow[t]{2}{*}{ Efficiency $*$ Hippocratic Oath * Medical Framing } & & & $-2.496^{* *}$ & \\
\hline & & & {$[1.242]$} & \\
\hline \multirow[t]{2}{*}{ Male } & & & & $-2.032^{*}$ \\
\hline & & & & {$[1.075]$} \\
\hline \multirow[t]{2}{*}{ Efficiency $*$ Male } & & & & $1.833^{* * *}$ \\
\hline & & & & {$[0.600]$} \\
\hline \multirow[t]{2}{*}{ Medical Framing * Male } & & & & 1.387 \\
\hline & & & & {$[1.028]$} \\
\hline \multirow[t]{2}{*}{ Hospice Receiver * Male } & & & & 1.206 \\
\hline & & & & {$[1.002]$} \\
\hline \multirow[t]{2}{*}{ Hippocratic Oath * Male } & & & & 0.043 \\
\hline & & & & {$[1.037]$} \\
\hline \multirow[t]{2}{*}{ Sequence 1} & -0.720 & -0.781 & -0.720 & -0.802 \\
\hline & {$[0.704]$} & {$[0.693]$} & {$[0.703]$} & {$[0.698]$} \\
\hline \multirow[t]{2}{*}{ Sequence 2} & -0.385 & -0.383 & -0.377 & -0.442 \\
\hline & {$[0.758]$} & {$[0.758]$} & {$[0.757]$} & {$[0.750]$} \\
\hline \multirow[t]{2}{*}{ Sequence 4} & 0.477 & 0.421 & 0.448 & 0.356 \\
\hline & {$[0.643]$} & {$[0.636]$} & {$[0.640]$} & {$[0.665]$} \\
\hline \multirow[t]{2}{*}{ Constant } & $2.542^{* * *}$ & $2.714^{* * *}$ & $2.643^{* * *}$ & $3.442^{* * *}$ \\
\hline & {$[0.689]$} & {$[0.791]$} & {$[0.683]$} & {$[0.822]$} \\
\hline \multirow[t]{2}{*}{ Sigma } & $4.496^{* * *}$ & $4.446^{* * *}$ & $4.471 * * *$ & $4.435^{* * *}$ \\
\hline & {$[0.234]$} & {$[0.234]$} & {$[0.234]$} & {$[0.231]$} \\
\hline Observations & 1,060 & 1,060 & 1,060 & 1,060 \\
\hline$F$-test sequence dummies ( $p$-value) & 0.27 & 0.26 & 0.29 & 0.29 \\
\hline
\end{tabular}

Notes: Robust standard errors in brackets, clustered by subject, ${ }^{* * *} \mathrm{p}<0.01,{ }^{* *} \mathrm{p}<0.05,{ }^{*} \mathrm{p}<0.1$ 
Table A.2: Tobit regressions predicting units provided in the cost dispersion games (games 5-12)

\begin{tabular}{|c|c|c|c|c|c|c|}
\hline \multirow[b]{2}{*}{ Explanatory variable } & \multicolumn{3}{|c|}{$\begin{array}{l}\text { Interested cost } \\
\text { dispersion games }\end{array}$} & \multicolumn{3}{|c|}{$\begin{array}{l}\text { Disinterested cost } \\
\text { dispersion games }\end{array}$} \\
\hline & $(1)$ & $(2)$ & $(3)$ & $(4)$ & $(5)$ & $(6)$ \\
\hline \multirow[t]{2}{*}{ Efficiency } & $1.668^{* * *}$ & $1.668^{* * *}$ & $1.412^{* * *}$ & $1.971^{* * *}$ & $1.979^{* * *}$ & $1.844^{* * *}$ \\
\hline & {$[0.220]$} & {$[0.220]$} & {$[0.404]$} & {$[0.225]$} & {$[0.226]$} & {$[0.431]$} \\
\hline \multirow[t]{2}{*}{ Medical Framing } & 0.063 & 0.645 & 0.177 & 0.699 & 1.051 & -0.771 \\
\hline & {$[0.476]$} & {$[0.787]$} & {$[0.612]$} & {$[0.456]$} & {$[0.804]$} & {$[0.932]$} \\
\hline \multirow[t]{2}{*}{ Hospice Receiver } & $1.102^{* *}$ & $1.768^{* *}$ & $1.096^{* *}$ & $2.222^{* * *}$ & $3.139^{* * *}$ & $2.185^{* * *}$ \\
\hline & {$[0.468]$} & {$[0.812]$} & {$[0.466]$} & {$[0.464]$} & {$[0.862]$} & {$[0.459]$} \\
\hline \multirow[t]{2}{*}{ Hippocratic Oath is shown } & -0.353 & -0.179 & 0.117 & $-0.807^{*}$ & $-1.834^{* *}$ & 0.256 \\
\hline & {$[0.470]$} & {$[0.873]$} & {$[0.610]$} & {$[0.458]$} & {$[0.822]$} & {$[0.943]$} \\
\hline \multirow[t]{2}{*}{ Medical Framing * Hippocratic Oath } & & -0.041 & & & $1.643^{*}$ & \\
\hline & & [0.943] & & & {$[0.904]$} & \\
\hline \multirow[t]{2}{*}{ Hospice Receiver $*$ Hippocratic Oath } & & -0.263 & & & 0.396 & \\
\hline & & {$[0.942]$} & & & {$[0.905]$} & \\
\hline \multirow[t]{2}{*}{ Hospice Receiver $*$ Medical Framing } & & -1.040 & & & $-2.251^{* *}$ & \\
\hline & & {$[0.943]$} & & & {$[0.898]$} & \\
\hline \multirow[t]{2}{*}{ Efficiency $*$ Hippocratic Oath } & & & 0.373 & & & $0.883^{*}$ \\
\hline & & & {$[0.600]$} & & & {$[0.511]$} \\
\hline \multirow[t]{2}{*}{ Efficiency $*$ Medical Framing } & & & 0.073 & & & -0.265 \\
\hline & & & {$[0.547]$} & & & {$[0.483]$} \\
\hline \multirow[t]{2}{*}{ Efficiency $*$ Hippocratic Oath * Medical Framing } & & & 0.032 & & & $-0.794^{*}$ \\
\hline & & & {$[0.719]$} & & & {$[0.412]$} \\
\hline \multirow[t]{2}{*}{ Sequence 1} & 0.045 & 0.023 & 0.045 & -0.043 & -0.110 & -0.063 \\
\hline & {$[0.707]$} & {$[0.711]$} & {$[0.709]$} & {$[0.683]$} & {$[0.683]$} & {$[0.683]$} \\
\hline \multirow[t]{2}{*}{ Sequence 2} & -0.254 & -0.294 & -0.255 & -0.931 & -0.968 & -0.918 \\
\hline & {$[0.692]$} & {$[0.697]$} & {$[0.693]$} & {$[0.673]$} & {$[0.675]$} & [0.669] \\
\hline \multirow[t]{2}{*}{ Sequence 4} & -0.476 & -0.486 & -0.465 & -0.639 & -0.698 & -0.702 \\
\hline & {$[0.627]$} & {$[0.624]$} & {$[0.631]$} & {$[0.613]$} & {$[0.607]$} & {$[0.605]$} \\
\hline \multirow[t]{2}{*}{ Constant } & $6.788^{* * *}$ & $6.435^{* * *}$ & $6.469 * * *$ & $7.659 * * *$ & $7.645^{* * *}$ & $7.850 * * *$ \\
\hline & {$[0.720]$} & {$[0.728]$} & {$[0.741]$} & {$[0.765]$} & {$[0.818]$} & {$[1.008]$} \\
\hline \multirow[t]{2}{*}{ Sigma } & $4.177^{* * *}$ & $4.169^{* * *}$ & $4.190^{* * *}$ & $4.083^{* * *}$ & $4.031^{* * *}$ & $4.077^{* * *}$ \\
\hline & {$[0.232]$} & {$[0.232]$} & {$[0.233]$} & {$[0.210]$} & {$[0.209]$} & {$[0.211]$} \\
\hline Observations & 1,048 & 1,048 & 1,050 & 1,048 & 1,048 & 1,052 \\
\hline$F$-test sequence dummies: (p-value) & 0.83 & 0.83 & 0.84 & 0.43 & 0.41 & 0.41 \\
\hline
\end{tabular}

Notes: Robust standard errors in brackets, clustered by subject, ${ }^{* * *} \mathrm{p}<0.01,{ }^{* *} \mathrm{p}<0.05,{ }^{*} \mathrm{p}<0.1$ 